\title{
THE LABORATORY TEST RIG WITH MINIATURE JET ENGINE TO RESEARCH AVIATION FUELS COMBUSTION PROCESS
}

\section{LABORATORYJNE STANOWISKO HAMOWNIANE MINIATUROWEGO SILNIKA ODRZUTOWEGO DO BADAŃ PROCESU SPALANIA PALIW LOTNICZYCH}

\author{
Bartosz Gawron, Tomasz Bialecki \\ Instytut Techniczny Wojsk Lotniczych \\ e-mail: bartosz.gawron@itwl.pl, tomasz.biatecki@itwl.pl
}

\begin{abstract}
This article presents laboratory test rig with a miniature turbojet engine (MiniJETRig - Miniature Jet Engine Test Rig), that was built in the Air Force Institute of Technology. The test rig has been developed for research and development works aimed at modelling and investigating processes and phenomena occurring in full scale jet engines. In the article construction of a test rig is described, with a brief discussion on the functionality of each of its main components. Additionally examples of measurement results obtained during the realization of the initial tests have been included, presenting the capabilities of the test rig.
\end{abstract}

Keywords: miniature turbojet engine, combustion process, aviation fuels, exhaust gases

Streszczenie: Tematem publikacji jest laboratoryjne stanowisko hamowniane MiniJETRig (Miniature Jet Engine Test Rig) zbudowane w oparciu o miniaturowy silnik odrzutowy, wytworzone $w$ Instytucie Technicznym Wojsk Lotniczych. Stanowisko przeznaczone jest do realizacji prac badawczo - rozwojowych, majacych na celu modelowanie oraz badanie procesów i zjawisk zachodzacych $w$ rzeczywistych silników odrzutowych. $W$ artykule przedstawiono budowe stanowiska wraz z krótkim opisem funkcjonalnym poszczególnych elementów składowych. Zaprezentowano również przyktadowe wyniki pomiarowe uzyskane podczas realizacji wstęnych testów hamownianych, prezentujace możliwości badacze stanowiska.

Stowa kluczowe: miniaturowy silnik odrzutowy, proces spalania, paliwa lotnicze, gazy spalinowe 
The laboratory test rig with miniature jet engine to research aviation fuels... Laboratoryjne stanowisko hamowniane miniaturowego silnika odrzutowego...

\section{Introduction}

In today's research and development works relating to transport more and more space is devoted to issues related to the process of fuel combustion in various types of engines and the reduction of harmful emissions into the atmosphere. Many international research programs are aimed at developing new, greener solutions for various industries. Also international conferences and symposia are organized, with environmental impact as main topics, to promote and initiate actions aimed at reduction of harmful substances emission during operation of various means of transport.

The problem of $\mathrm{CO}_{2}$ emissions reduction into the atmosphere, and measurements of harmful components, is especially important and actual for global aviation. Air transport is currently the fastest growing source of carbon dioxide emissions. For this reason, the European aviation sector has been put within the emissions trading system, designed to reduce harmful emissions. Airlines have begun to monitor $\mathrm{CO}_{2}$ emissions and must prepare for implementation of environmental regulations.

These activities have been initiated by the designation by the International Air Transport Association (IATA), that set three goals for aviation sector [1]:

- A short - term goal to improve fuel consumption efficiency by an average of $1.5 \%$ per annum through 2020 on the basis of $\mathrm{CO}_{2}$ emissions per revenue tone kilometer (RTK);

- a mid - term target to stabilize net $\mathrm{CO}_{2}$ emissions in aviation from 2020 onward (carbon - neutral growth);

- a long - term goal to reduce aviation net carbon emissions by $50 \%$ in 2050 , as compared to 2005.

One of major methods of harmful combustion products emissions reduction is implementation to the fossil fuel various components, including biocomponents and biofuels. In recent years in the Air Force Institute of Technology (AFIT) many research works have been carried out $[2,3,4]$ dealing with the use of alternative fuels for aviation. Due to the technical feasibility, cost and biofuels availability, the majority of these works ended up at the laboratory level. In authors' opinion, nowadays availability of new, experimental fuels, or components is the major restriction for large - scale tests on real jet engines. The reason for that situation is that most of innovative technologies for aviation biofuels are in experimental scale, and just small volumes of such products are available for tests.

AFIT, being leading research organisation in Poland within fuels for aviation, recognised as extremely important to create a specialized research facilities, that can work with small volumes of fuels. As a result of efforts undertaken in this area, in the Department of Fuels and Lubricants laboratory test rig has been designed and developed, equipped with miniature turbojet engine. The project was financed by the Ministry of Science and Higher Education.

One of the basic research applications of MiniJETRig is testing of aviation fuels combustion process (fossil and alternative). 


\section{Laboratory test rig}

MiniJETRig (fig. 1) is equipped with the following elements:

- miniature turbojet engine;

- dedicated measuring equipment, which includes:

- exhaust analyser;

- particulate matter analyser;

- control system with data acquisition based on the measurement cards.

Additionally test rig is fully adjustable to specific user's needs. It is possible to add any other measuring instrumentation.

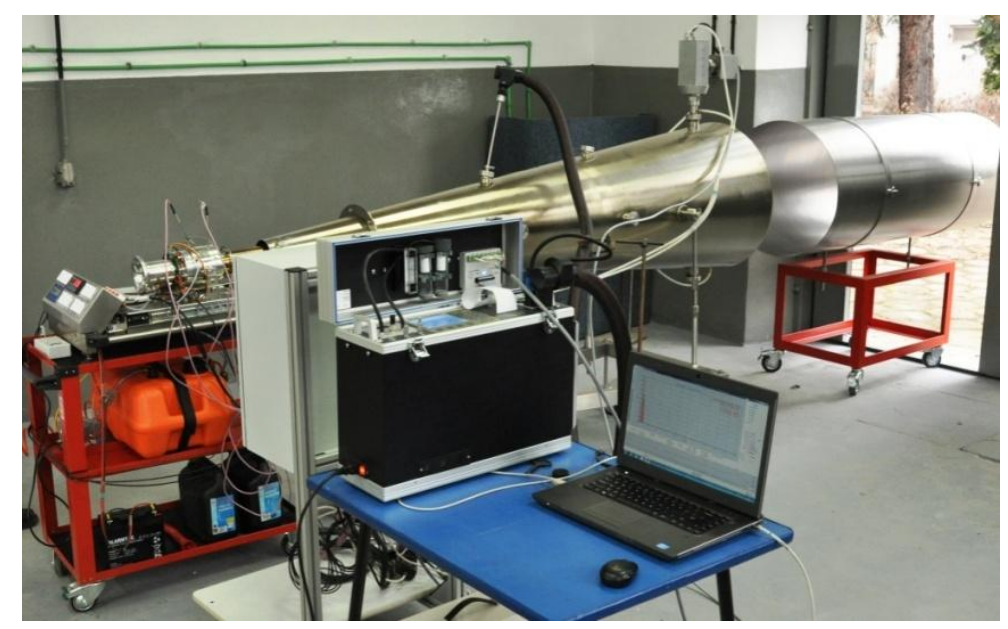

Fig. 1 MiniJETRig.

\section{Miniature turbojet engine}

The key component of the test rig is the miniature turbojet engine, working in the range of $33000-120000 \mathrm{rpm}$ and with the maximum thrust of $140 \mathrm{~N}$. It includes single - stage radial compressor driven by a single - stage axial turbine and an annular combustion chamber with a set of vaporizer tubes. For research purposes miniature jet engines have been prepared in two versions: metal and glass housings (fig. 2). Furthermore two exhaust systems: with straight duct and convergent nozzle are available

During the tests it is possible to display online and record basic jet engine parameters: thrust, rotational speed, exhaust gas temperature and fuel consumption. It is also possible to measure the pressure and temperature along the engine gas path in selected characteristic points:

- pressure measurement - inlet, behind compressor;

- temperature measurement - inlet, behind compressor, behind combustion chamber (around combustion chamber in 6 selected points), behind turbine. 
The laboratory test rig with miniature jet engine to research aviation fuels... Laboratoryjne stanowisko hamowniane miniaturowego silnika odrzutowego...
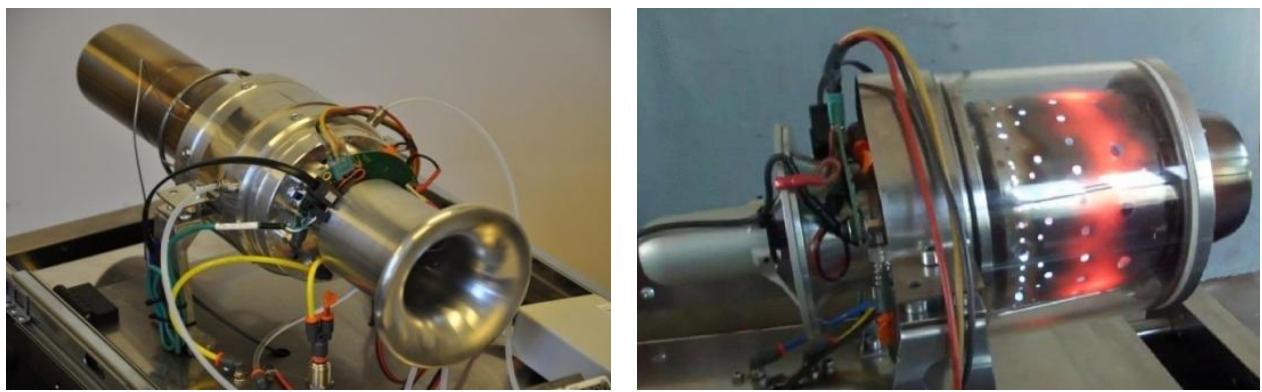

Fig. 2 The miniature jet engine in two versions: metal and glass housing.

Miniature jet engine is protected by an Electronic Control Unit (ECU). ECU controls: maximum and minimum value of exhaust gas temperature (EGT) and revolutions per minute, pump control voltage as a function of RPM. The derogation in each of the above parameters is treated as an emergency and then jet engine is automatically shut down.

The main advantage of the miniature turbojet engine application is small amount of fuel necessary for tests. Fuel consumption is approximately 0.5 litre per minute at the maximum thrust. Triple valve used in the test rig allows for switching between different fuels during the same test run. Those factors allow for cost reduction and verification (in conditions similar to those specific for full scale jet engines) of technologies being at the early or experimental stage, when only small amounts of fuel is available.

\section{Portable exhaust analyser}

MiniJETRig is also equipped with portable exhaust analyser, which is used to take samples of exhaust gases from the engine and deliver it through a heated hose to the analyzing unit. In block of analyser electrochemical sensors are assembled for measurement of $\mathrm{O}_{2}, \mathrm{CO}, \mathrm{NO}, \mathrm{NO}_{2}, \mathrm{SO}_{2}$ and two NDIR sensors for measuring infrared $\mathrm{CO}_{2}$ and $\mathrm{C}_{\mathrm{x}} \mathrm{H}_{\mathrm{y}}$. The individual components of exhaust gas are measured in a defined range and resolution of 1 or $0.1 \mathrm{ppm}$.

Exhaust gas concentrations may be presented on the display of the analyser as: volumetric concentration (\% or $\mathrm{ppm})$, mass concentration $\left(\mathrm{mg} / \mathrm{m}^{3}\right)$ and mass concentration in relation to the oxygen $\left(\mathrm{mg} / \mathrm{m}^{3}\right)$.

Exhaust analyser also allows to measure exhaust gas temperature. In addition, the analyser has a built-in integral box of analog outputs that allow to send information about the analysed concentration of exhaust gases to external measurement cards.

\section{Particulate matter analyser}

Another main element of the test rig is particulate matter analyser. This analyser allows to measure online of the size and amount of particulate matter emitted by the engine. It consists of measurement head and electronic unit controlled by a computer. The analyser uses the method of transmitted light measurement, 
where the flux of infrared radiation is scattered by particles passing through the measurement zone. Each particle represents electrical signal proportional to the diameter of the spherical particles. If the particle is not spherical, amplitude pulse depends on the orientation of the particles in the measurement zone. The analyser allows for:

- fast and multiple measurements of particulate matters in the range of from 0.5 to $300 \mu \mathrm{m}$;

- particulates size distribution, divided into 256 equal measurement class, or 11 any user - defined classes;

- gravimetric measurement.

Probes of the two analysers are mounted in a specially designed collector located directly behind the engine. Measuring points for the probes of the analysers have been chosen to allow simultaneous measure of both gaseous components and particulate matters.

\section{Control system with data acquisition}

Special software has been developed for MiniJETRig, allowing for data collection from active measurement channels during the test. Data recording system is based on block of measurement cards registering following signals: current, voltage, thermocouple and digital. The block is connected with the computer workstation where the application is installed (fig. 3).

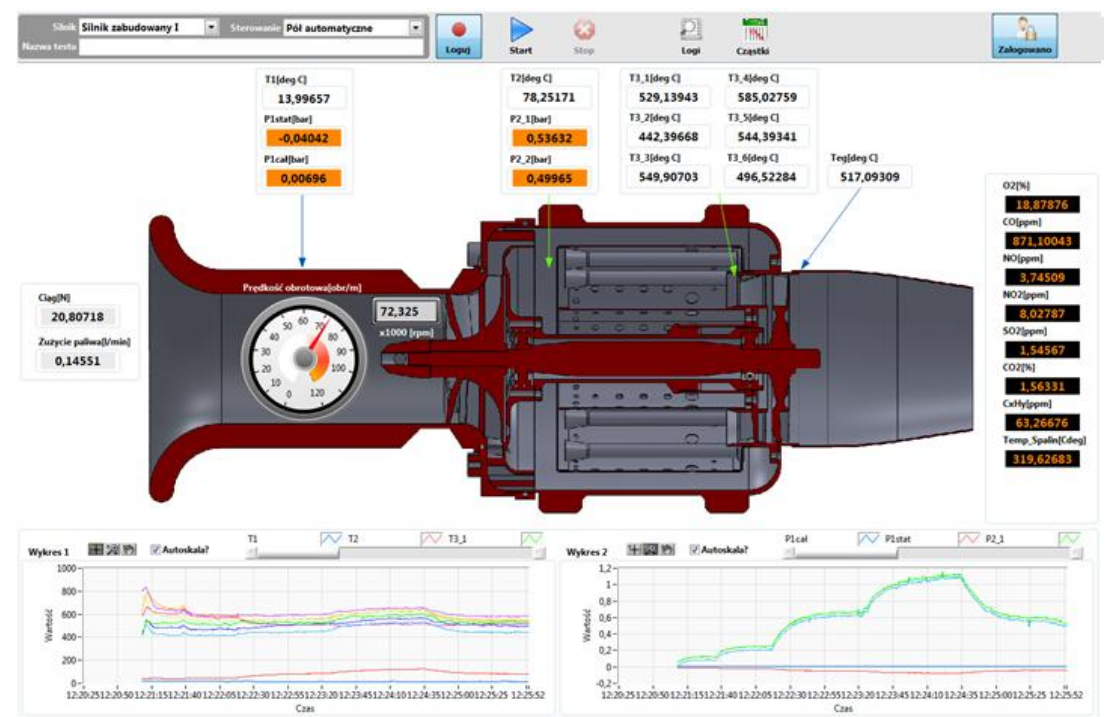

Fig. 3 LabView software.

The software has been developed in LabView - graphical programming language, and - as well as data registration - it allows to control the operation of jet engine and e.g. define the profile of the test run. 
The laboratory test rig with miniature jet engine to research aviation fuels... Laboratoryjne stanowisko hamowniane miniaturowego silnika odrzutowego...

There are three ways to control the operation of mini jet engine:

- manually: user controls the engine by built - in driver;

- semi - automatically: user controls the engine and measurement process by application in LabView;

- automatically: profile of the test run is selected from the library and is controlled by application.

\section{Measurement capabilities}

All of the test were carried out in the Department of Fuels and Lubricants at the Air Force Institute of Technology. Measurement capabilities are shown below, on fig. 5 - 10. MiniJETRig was run on conventional fuel used in the aviation industry Jet A - 1 with $4 \%$ AeroShell Turbine Oil 560. This volume of oil is recommended by the engine manufacturer for bearing lubrication.

The research was carried out with different rotational speed according the profile of the engine test (fig. 4). Tests were conducted with the miniature turbojet engine, which was equipped of exhaust system with: straight duct and convergent nozzle. Tests were repeated for each listed below type of exhaust system at least three times.

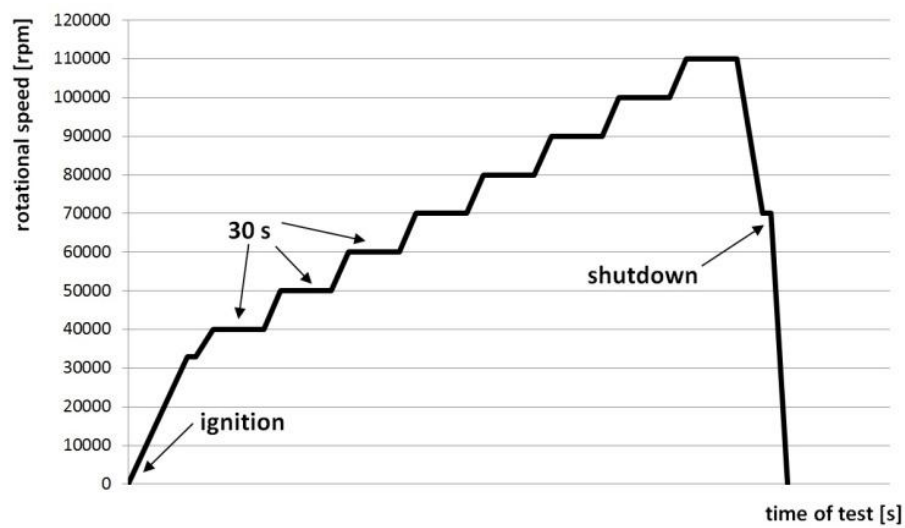

Fig. 4 Profile of the engine test

Upon ignition, the engine was given maximum of 60 seconds to reach a steady state whereby the engine speed remained constant at an approximately $33000 \mathrm{rpm}$ (idle speed). Rotational speed was raised from 40000 to $110000 \mathrm{rpm}$ for exhaust system with straight duct or to $100000 \mathrm{rpm}$ for exhaust system with convergent nozzle with the interval at $10000 \mathrm{rpm}$. Steady state (in the range $\pm 2000 \mathrm{rpm}$ ) on each interval lasted 30 seconds. At the end of a profile of the test run, rotational speed was decreased to $70000 \mathrm{rpm}$ and engine was shut down. Sampling rate was five times per second.

Fig. $5-7$ present miniature jet engine main parameters trends as a function of engine speed. 
Bartosz Gawron, Tomasz Biatecki

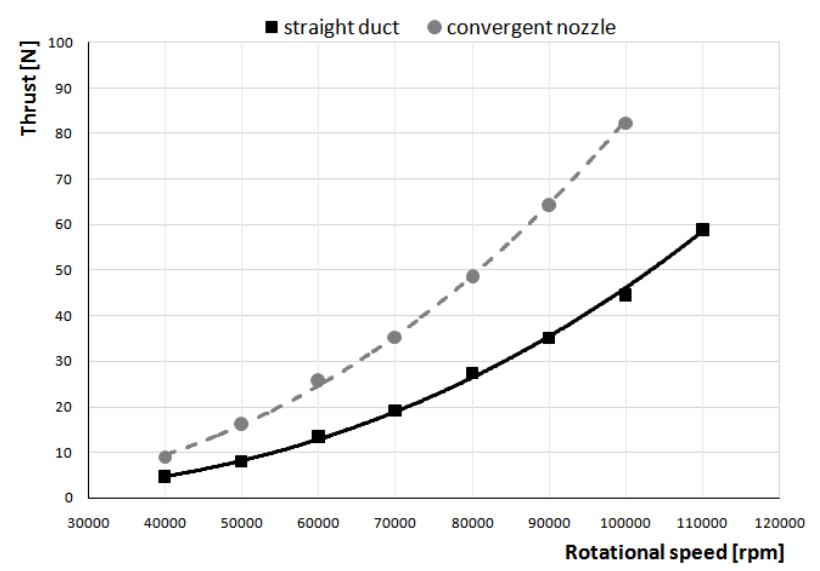

Fig. 5 Thrust as a function of engine speed



Fig. 6 Fuel consumption as a function of engine speed

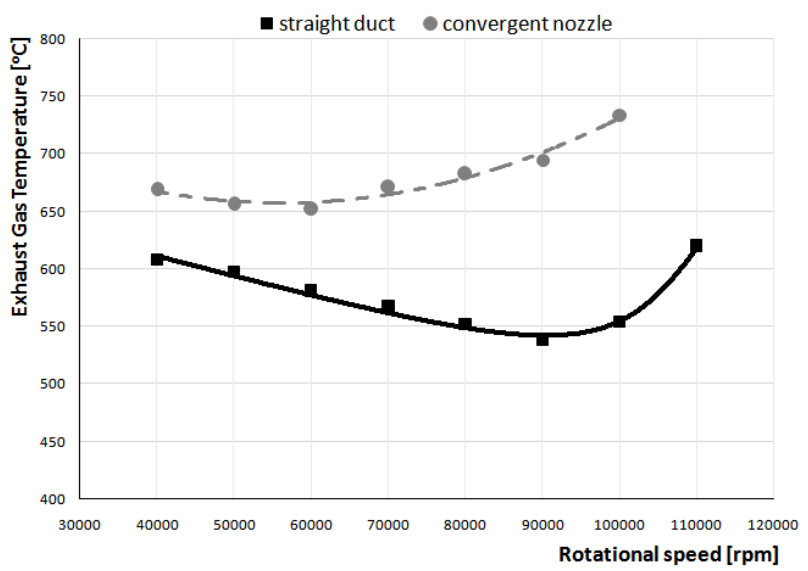

Fig. 7 Exhaust Gas Temperature as a function of engine speed 
The laboratory test rig with miniature jet engine to research aviation fuels... Laboratoryjne stanowisko hamowniane miniaturowego silnika odrzutowego...

Trends of engine measured parameters are similar to the characteristics obtained on a full scale jet engines $[5,6]$. Thrust produced from the engine is proportional to the amount of fuel consumed. Use of convergent nozzle as compared with straight duct gives expected results - parameters: thrust, fuel consumption and exhaust gas temperature are reached higher value.

Selected exhaust gas components concentrations $\left(\mathrm{CO}, \mathrm{CO}_{2}\right.$ and $\left.\mathrm{NO}_{\mathrm{x}}\right)$ are shown on fig. $8-10$. The exhaust gas sample probe was positioned in the center of the exhaust stream:

- at the end of straight duct;

- about $10 \mathrm{~cm}$ from the convergent nozzle.

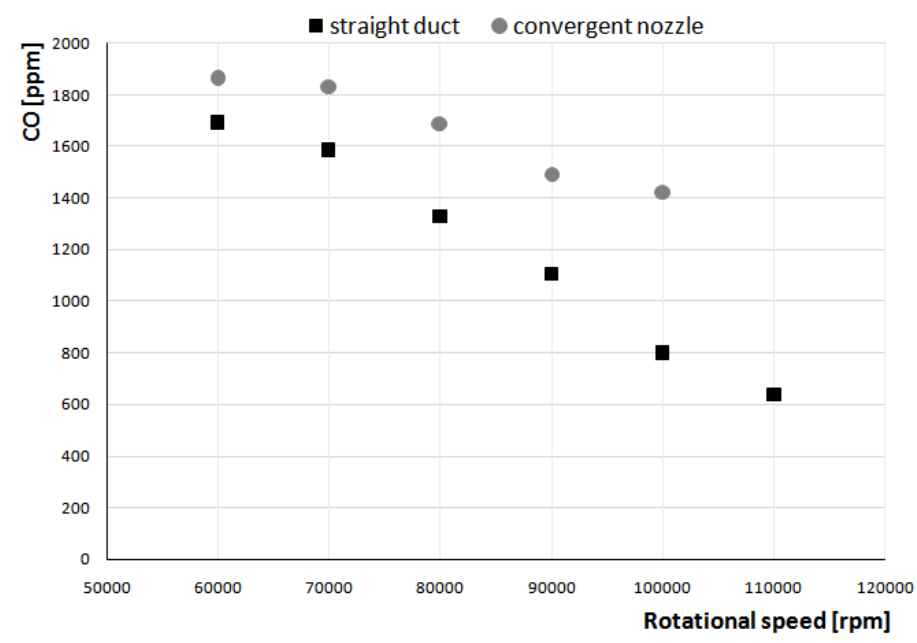

Fig. 8 CO emission as a function of engine speed

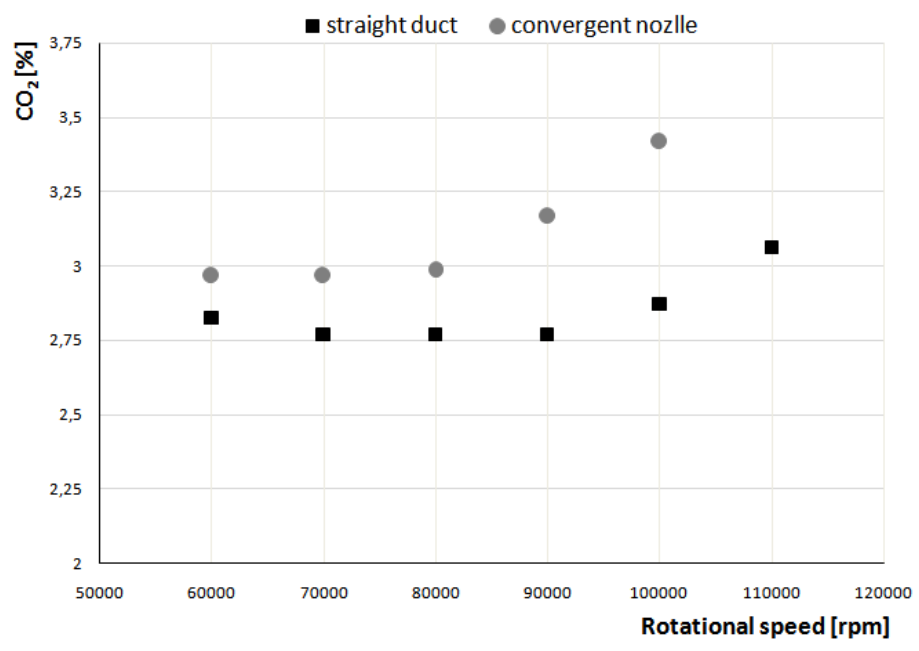

Fig. $9 \mathrm{CO}_{2}$ emission as a function of engine speed 


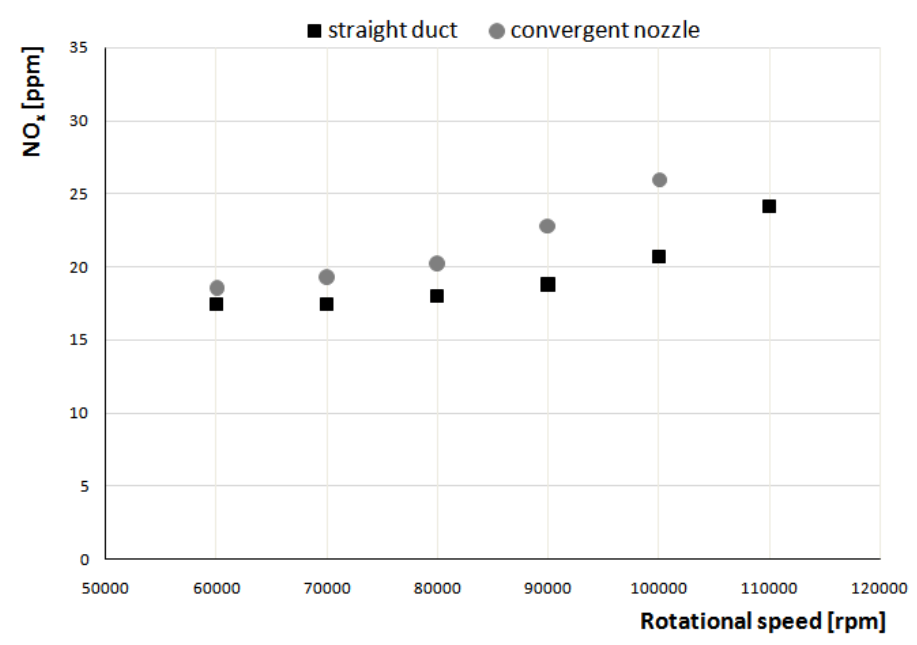

Fig. $10 \mathrm{NO}_{x}$ emission as a function of engine speed

General trend for $\mathrm{CO}$ emissions is that they are highest at low power conditions, and decrease with increasing power output. The $\mathrm{CO}$ data (fig. 8) follow this trend in presented range of rotational speed. Fig. 10 shows that $\mathrm{NO}_{\mathrm{x}}$ emission increased as engine speed increased. This follows the trend found in the literature [7].

Fig. 11 - 13 show comparative research results of emission, between MiniJETRig and turbofan engine CFM56 [8], which is used for commercial aircraft propulsion. Trends of emission selected exhaust components: $\mathrm{CO}, \mathrm{CO}_{2}, \mathrm{NO}_{\mathrm{x}}$ on a laboratory test rig is similar to the characteristics obtained on a full scale jet engine. It is seen, that ranges of reached values for $\mathrm{CO}_{2}$ emission are similar.

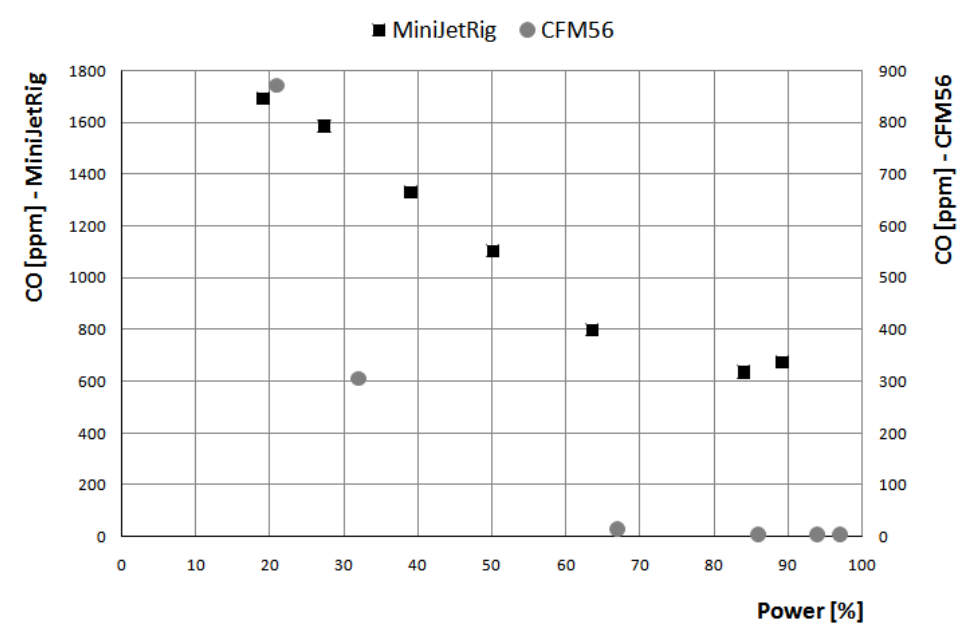

Fig. 11 CO emission for MiniJETRig and CFM56 [8] 
The laboratory test rig with miniature jet engine to research aviation fuels... Laboratoryjne stanowisko hamowniane miniaturowego silnika odrzutowego...

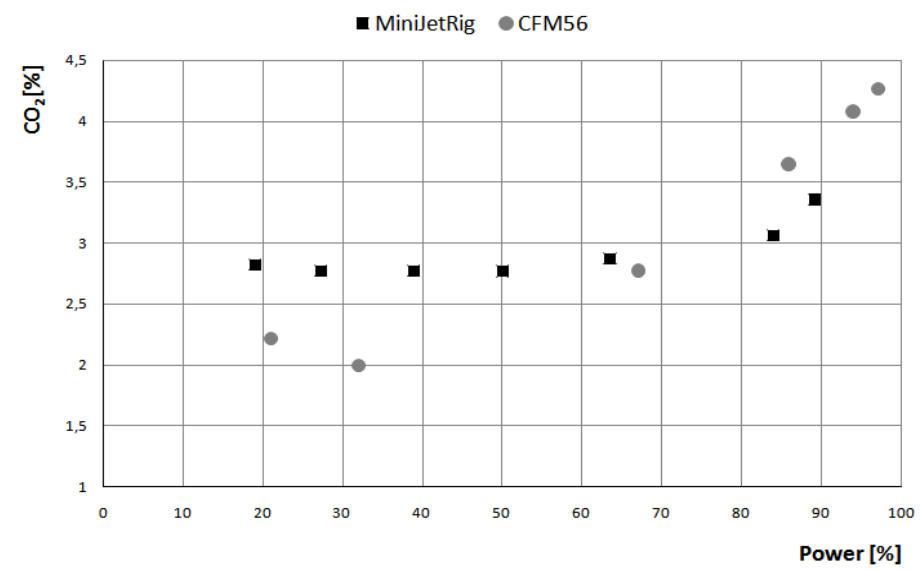

Fig. $12 \mathrm{CO}_{2}$ emission for MiniJETRig and CFM56 [8]

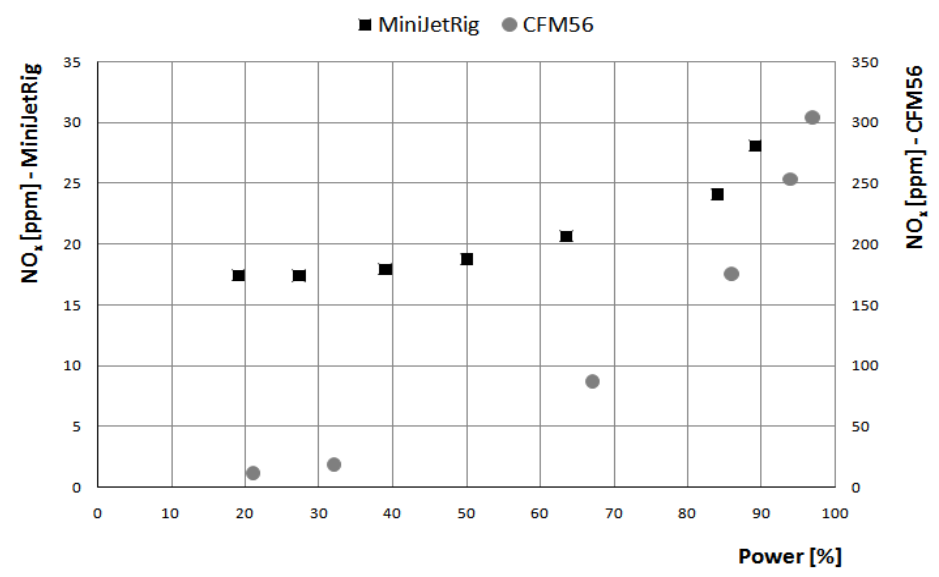

Fig. $13 N_{x}$ emission for MiniJETRig and CFM56 [8]

\section{Conclusion}

The most important advantage of presented test rig is fact, that it is a link between laboratory tests of fuels/biofuels (where relatively small quantity of fuels are necessary) and real jet engine tests (where large volume of tested fuel must be delivered). Thus, especially in case of biofuels and biocomponents from experimental production plants or experimental processes, presented equipment may be extremely interesting.

The test rig consists of modules. Thus additional equipment can be designed and mounted, which allows to easily adapt it to research and verification of different technologies for aviation: alternative fuels and biocomponents, innovative materials and coatings, advanced construction solutions; diagnostic systems and sensors. 
Trends of measured parameters on a test rig are similar to the characteristics obtained on a full scale jet engines. The above confirms, that test run of miniature turbojet engine reflects the processes and phenomena in a real jet engines.

\section{References}

[1] ATAG 2013: Reducing emissions from aviation through carbon neutral growth from 2020, Working paper developed for the 38th ICAO Assembly September/October 2013.

[2] Dzięgielewski W., Gawron B.: Investigations to check applicability of 1st generation biocomponents to fuels for turbine aircraft engines, Research Works of Air Force Institute of Technology, No. 30, 2012.

[3] Dzięgielewski W., Gawron B., Kaźmierczak U., Kulczycki A.: Butanol/biobutanol as a component of an aviation and diesel fuel, Journal of KONES, No. 2, 2014.

[4] Gawron B., Kaźmierczak U.: Hydrocarbon biocomponents use in aviation fuels preliminary analysis of issues, Journal of KONBIN, No. 3,4 (27,28), 2013.

[5] Walsh, P. P., Fletcher P.: Gas turbine performance, second edition, 2004.

[6] Lobo P., Whitefield P. D., Hagen D. E. and others: The Development of exhaust speciation profiles for commercial jet engines. Final Report, 2007.

[7] Lefebvre A. H., Ballal D. R.: Gas turbine combustion. Alternative fuels and emissions, third edition, 2010.

[8] Yay O. D., Yilmaz E., Turgot E.T., Cavcar M., Ucarsu M., Usanmaz O., Dogeroglu T., Armutlu K.: CFM56-7B24 series aircraft engine emission measurements in test cell environment and emission index development, In:16th GEIA Conference, 2014.

This article was presented at the 6th European Conference for Aeronautics and Space Sciences in Krakow (EUCASS 2015).

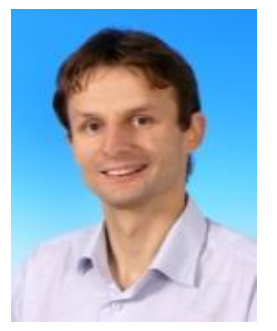

dr ini. Bartosz Gawron, absolwent Wojskowej Akademii Technicznej na kierunku mechatronika, specjalność: samoloty $i$ śmiglowce, w latach 2008-2012 doktorant na studiach III stopnia w WAT na Wydziale Mechatroniki i Lotnictwa, od 09.2012 doktor nauk technicznych $w$ dyscyplinie naukowej mechanika. Aktualnie pracownik naukowy w Instytucie Technicznym Wojsk Lotniczych.

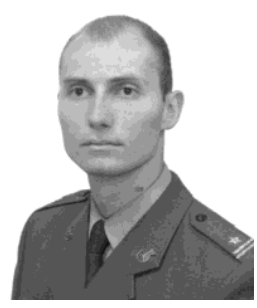

mjr mgr inz. Tomasz Bialecki, absolwent Wojskowej Akademii Technicznej, w latach 2010 - 2014 r. Szef Stużby Materiatów Pędnych i Smarów w lotniczej jednostce wojskowej. Od 2014 r. pracownik Zakładu Materiałów Pędnych i Smarów ITWL. 
The laboratory test rig with miniature jet engine to research aviation fuels... Laboratoryjne stanowisko hamowniane miniaturowego silnika odrzutowego... 